\title{
Accessory Thyroid Gland In A Patient with Hypothyroid State
}

\author{
MA MANNAN, ${ }^{1}$ RUBI NA BEGUM, ${ }^{2}$ MUHAMMAD HAFIZUR RAHMAN, ${ }^{3}$ KHALED HASSAN, ${ }^{4}$ MI RZAAZIZL HOQUE 5
}

\begin{abstract}
:
A 40 yrs female muslim housewife attended Endocrinology department of Dhaka Medical College Hospital with the complaints of swelling in front of neck, alone with dryness of the skin, cold intolerance, constipation and menorrhagia. Physical examination and laboratory investigations substantiated the diagnosis of accessory thyroid gland in front of neck above the isthmus of the thyroid gland. RAIU and scanning showed normally present thyroid gland with accessory thyroidal nodular swelling in the midline in the upper part of front of neck. USG of the thyroid gland showed normal size of thyroid gland with coarse echo texture. A hypo echoic solid thyroid nodule was also seen above the isthmus of the thyroid gland, measuring about $2.4 \mathrm{~cm} 2.2 \mathrm{~cm}$. Thyroid function tests revealed hypothyroidism. She is on thyroid hormone replacement therapy. This rare presentation of accessory thyroid gland with hypothyroid state led us to report the case.
\end{abstract}

Keywords: Accessory thyroid gland, Hypothyroidsm, Ectopic, Bangladesh

\section{Introduction:}

The organogenesis of the thyroid gland in human is often disturbed leading to a variety of morphological variation of the gland, such as hypoplasia, ectopy, hemiagenesis and agenesis. Thyroid gland is the first endocrine gland to appear during the embryogenic period. It begins to develop about 24 days after fertilization, from a median endodermal thickening in the floor of the primitive pharynx between the first and second branchial arches, just caudal to future site of the medial tongue bud. This thickening soon forms a down growth knows as thyroid diverticulum. As the embryo elongates and the tongue grows, the developing thyroid gland descends in to the neck, passing ventral to the developing hyoid bone and the lateral cartilages. The developing thyroid gland is connected to the tongue by the thyroglossal duct. The opening of this duct in the tongue is called the foramen cecum. The thyroid diverticulum is first hallowed but soon become solid and divides. The right and left lobes are connected by isthmus that lies anterior to the second and third tracheal rings. By $7^{\text {th }}$ wk the thyroid gland has usually reached its final site in the neck. By this time the thyroglossal duct has normally degenerated and disappeared. A pyramidal lobe is present in about $50 \%$ of cases and may be attached to hyoid bone by fibrous or muscular tissue .The pyramidal lobe represents a persistent portion of the inferior end of the thyroglossal duct. The small opening the thyroglossal duct persists as a small pit, the foramen cecam of the tongue. The lateral anlage arises as a diverticulum from the fourth and fifth pharyngeal pouches and forms the para-follicular cells which produce calcitonin. ${ }^{1}$

Rarely the thyroid gland fails to descend, resulting in a lingual thyroid. ${ }^{2}$ Accessory thyroid tissue may appear in the tongue or in the neck superior to the thyroid gland. Carotid body tumor sometimes may confuse with an accessory thyroid gland of the neck. Carotid body is a pinkish grey structure located within the adventitial layer of the posterior medial aspect of the common carotid bifurcation. Tumors arising from this body are called paragangliomas, because they arise from paragangliomas cells. No relation to the development of the thyroid gland is known. ${ }^{3}$

\section{Case report:}

A female Muslim housewife of age 40 yrs, hailing from Madanpur, Chittagong road, Dhaka was referred to the Department of Endocrinology, Dhaka Medical College Hospital with the complaint of neck swelling. The swelling had been present and asymptomatic for years with no progression. Family history did not reveal any thyroid disorder in $1^{\text {st }}$ degree relatives. She gave history of dryness of the skin, cold intolerance, constipation, menorrhagia and dysmenorrhoea. Clinically she was mildly anemic and non icteric, and she had mild ankle edema. Body hair distribution

1. Professor, Department of Endocrinology, Dhaka Medical College Hospital, Dhaka.

2. Senior Medical officer, Center for Nuclear Medicine \& Ultrasound, Dhaka Medical College Hospital Campus, Bangladesh Atomic Energy Commission;

3. Assistant Professor, Department of Endocrinology Dhaka Medical College Hospital Dhaka.

4. Medical Officer, Department of Endocrinology Dhaka Medical College Hospital, Dhaka.

5. Associate Professor, Department of Endocrinology Dhaka Medical College Hospital, Dhaka.

Correspondence: Prof. M A Mannan Department of Endocrinology, Dhaka Medical College and Hospital, Dhaka-E-mail : drmadem@yahoo.com 
was normal. There was no lymphadenopathy .Thyroid gland was normal in size and position. There was a small nodular swelling above the isthmus of the thyroid which was non tender but fixed to the underlying structures. The patient did not give any history of operation in the past. Her pulse rate was 80/min, blood pressure was 120/80 mm Hg, and skin was dry, pale and rough. System examinations revealed no other abnormalities.

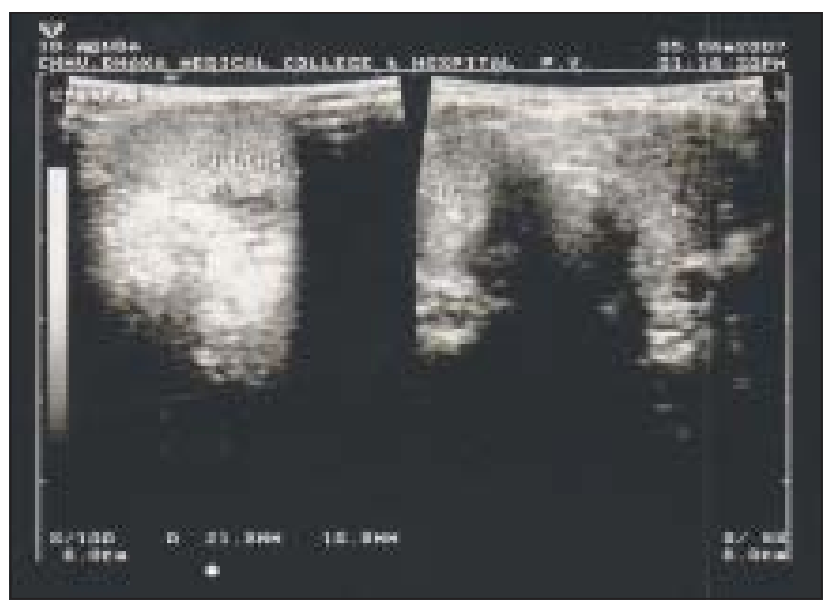

Fig.-1. USG of thyroid gland showing a hypo echoic solid nodule just above the isthmus measuring about $2.9 \times 2.2$ $\mathrm{cm}$.

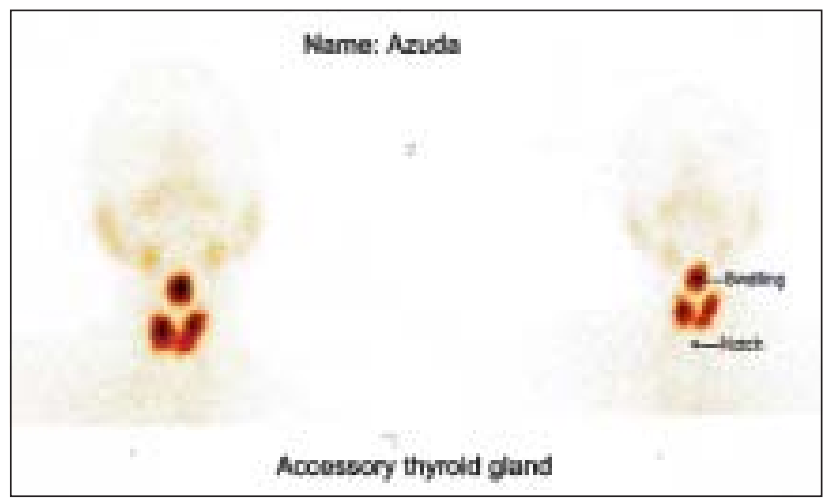

Fig.-2. Thyroid Scan with $99 m$ Tc showing extra thyroidal swelling above the thyroid gland.

\section{Investigations showed:}

$\mathrm{Hb}$ 65\%, WBC 7000/cu mm with N-70\%, L- 26\%, E-4\%, B $0 \%$. Blood sugar - fasting $5.0 \mathrm{mmol} / \mathrm{L}$, and $2 \mathrm{hr}$ after75gm glucose $7.2 \mathrm{mmol} / \mathrm{L}$. S creatinine $0.7 \mathrm{gm} / \mathrm{dl}$ and S. Urea 23mg/ dl. Urine R/M/E - normal. CXR and ECG- normal. S electrolytes: Na-141 mmol/L/l, K-4mmol/L, Cl- $104 \mathrm{mmol}$ and $\mathrm{TCO}_{2-} 25 \mathrm{mmol} / \mathrm{L}$. USG of whole abdomen - normal USG of thyroid gland - normal in size, course in echo texture. A hypo echoic solid nodule was seen just above the isthmus measuring about $2.9 \times 2.2 \mathrm{~cm}$ (Fig.1). Thyroid function test- $\mathrm{S}$ TT4 53.04 nmol/l (normal 55-173 nmol/L). S TT3 1.24 nmol/L (normal 1.32-3.75 nmol/L), S TSH $87.62 \mathrm{mU} / \mathrm{L}$ (normal 0.3-5.0 $\mathrm{mU} / \mathrm{L})$. FNAC of the nodular swelling - thyroid follicular cell with colloid material. Radioactive Iodine Uptake of Thyroid : $2 \mathrm{hr}=15 \%, 24 \mathrm{hr}=48 \%$. Thyroid Scan with 99m Tc $2 \mathrm{mCi} \mathrm{I/V}$ - extra thyroidal swelling above the thyroid cartilage (Fig.-2).

\section{Discussion:}

Ectopic thyroid tissue is defined as thyroid tissue located other than anterolaterally to the second to fourth tracheal cartilages. Since 1869, Hickmann first reported lingual thyroid, and then several reports of ectopic thyroid tissue have been published. ${ }^{4}$ The lingual location is most common, accounting for $90 \%$ of reported case. ${ }^{5,6}$ Other rare sites of ectopic thyroid are mediastinum, esophagus, lung, heart, aorta and abdomen. ${ }^{7,11-14}$ In $70 \%$ to $80 \%$ of cases ectopic thyroid tissue is the only functional thyroid tissue. ${ }^{4,15,16}$ But in our case we did not find a proper functioning thyroid gland which is evidence clinically and biochemically. A submandibular ectopic thyroid tissue with a normally functioning thyroid gland in its proper location has been reported only once. ${ }^{19}$ Sambola -Cabrer et $\mathrm{al}^{20}$ first reported ectopic thyroid tissue in the sub mandibular location in combination with a normally located but atrophic thyroid gland. In 1988, Ruben-field et al reported ectopic thyroid tissue at the carotid bifurcation contrast to our case; they did not find a proper functioning thyroid gland in its normal position. Several theories have been postulated to explain the origin of the ectopic thyroid tissue $^{17-20}$. Displacement during the course of embryonal development seems a logical explanation. Nicastri et al. ${ }^{21}$ reported that benign thyroid tissue may also metastasize to the cervical lymph nodes. Lastly we should follow up the case in a regular interval for future management including thyroid hormone replacement.

\section{Conflict of Interest: None}

\section{References:}

1. Moore KL . The developing human: clinically oriented embryology. $4^{\text {th }}$ ed. Toronto: W.B.saunders;1988.p184-7

2. Hazard JB, Smith DE. The thyroid. Baltimore, Md: Williums \& Wlkins;1964.p26

3. Dean HD . Carotid body tumors. In :Sabston DC Jr, edtor. Sabston's textbook of surgery. $15^{\text {th }}$ ed. Philadelphia: W.B.saunders; 1997.p1660

4. Hickmann W. Congental tumor of the base of the tongue, pressing down the epglottis on the larynx and causing death by suffocation sixteen hours after birth. Trans Pathol Soc Lond 1869;20:160-1

5. Larochelle D, Arcand P, Belzile M, et al. Ectopic thyroid tissue: a review of the literature. J Otolaryngol 1979;8:52330 
6. Pinter JE, Dominique CTA. Normal development of the hypothalamic- pituitary- thyroid axis. In : Braverman LE, Utiger RD, editors. Werner and Jugbar's the thyroid. $6^{\text {th }}$ ed. Philadelphia, Pa: Lippingcott;1991.p11-4

7. Arriaga MA, Meyers EN. Ectopic thyroid tissue in the retroesophageal superior mediastnum. Otolaryngol Head neck Surg 1988;99:338

8. Whale HL. Esophageal tumor of thyroid tissue. BMJ $1987 ; 2: 1921$

9. Simon M, Baczako K. Thyroid inclusion in the lung; metastasis of an occult carcinoma or ectopia? Pathol Res Pract 1989; 184: 263.

10. Casanova JB, Daly RC, Edwards BS, et al. Intracardiac ectopic thyroid . Ann Thorac Surg 2000;70:1694-6

11. Wlliams RJ, Lindop G, Butler J. Ectopic thyroid tissue on the ascending aorta: an operative finding. Ann Thorac Surg 2002;73:1642-3

12. Gungor B, Kebat T, Ozaslan C, et al, Intraabdominal ectopic thyroid presenting with hyperthyroidism; report of a case. Surg Today 2002;32:148-50

13. Shiraishi T, Imai H, Fukutone K, et al. Ectopic thyroid tissue in the adrenal gland. Hum Pathol 1999;30:105-8
14. Jamshidi M, Kasirye O, Smith DJ. Ectopic thyroid nodular goiter presenting as a porta hepatis mass. Am Surg 1998;64:305-6

15. Meyerson M, Smith HW. Lingual thyroid: a review. Conn Med 1966;30:341-4

16. Noyek AM, Friedberg J. Thyroglossal duct and ectopic thyroid disoeders. Otolaryngol Clin North Am 1981;14:187201

17. Kumar R, Sharma S, Marwah A , et al. Ectopic goiter masquerading as submandibular gland swelling. Clin Nucl Med 2001;26:306-9

18. Feller KU, Mavros A, Gaertner HJ, Ectopic submandibular thyroid tissue with a co existing active and normally located thyroid gland: case report and review of the literature. Oral Surg 2000;90:618-23

19. Akoz T, Erdogan B, Ayham M, Cinar F. Ectopic submandibular thyroid tissue. Rev Laryngol Otol Rhinol( Bord)1998;119:323-5

20. Sambola-Cabber I, Fernandez -Real JM, Ricart W, et al. Ectopic thyroid tissue presenting as a submandibular mass. Head neck 1996;18:87-90

21. Nicastri AD,Foote FW Jr, Frazell EL. Benign thyroid inclusions in cervical lymph nodes. JAMA 1965; 194: 1 